\title{
Flood Modeling Assessment: A Case of Bishnumati River
}

\author{
Noor Dangol \\ noordg16@gmail.com
}

\section{KEYWORDS}

Flood Modeling, Bishnumati River, HEC-RAS, Flood Hazard

\begin{abstract}
Flood, a common water induced disaster of a monsoon season, is the recurring phenomenon in Nepal. To study this disaster, different flood modelling had been conducted for different river basins following different modelling tools. This study describes the technical approach of probable flood vulnerability and hazard analysis of Bishnumati river catchment and analyze the result with previous study done for the same study area. The method adopted for previous study in 2009 was adopted in this study as well in order to compare the results. One dimensional hydraulic model HEC-RAS with HEC GeoRAS interface in co-ordination with Arc GIS was applied for the analysis.. Hazard maps, landuse vulnerability maps of various return periods (10 Yrs, 20Yrs, 50Yrs and 100Yrs), were prepared in ArcGIS. The results of flood frequency analyzed by WECS/ DHM method showed discharges of $445 \mathrm{~m}^{3} / \mathrm{s}, 541 \mathrm{~m}^{3} / \mathrm{s}, 648 \mathrm{~m} / \mathrm{s}$, $725 \mathrm{~m}^{3} / \mathrm{s}$ for 10,20, 50 and 100 years return period floods. The primary data of the study showed most of the flooding area had water depth greater than $3 \mathrm{~m}$. The assessment of the flood inundated area showed that large percentage of vulnerable area lied in built up areas followed by barren land.
\end{abstract}

\section{INTRODUCTION}

Flood is an unusual high stage of a river overflowing its bank and inundating the marginal lands. This may also due to shifting of the course of the river, earth quake causing bank erosion, or blocking of river, or breaching of the river flood banks (Kumar et al., 2017). Flooding is a result of heavy or continuous rainfall exceeding the absorptive capacity of soil and the flow capacity of rivers or streams. Excessive rainfall is the basic cause of a river flood but there are simultaneously other contributory factors. Data of last three decades shows that climate related disasters accounted for almost 25 per cent of deaths, 84 per cent of adversely affected people and 76 per cent of economic losses (MoHA, 2009).
Nepal's geographical location exposes it to extreme precipitation, seismic activities and landslides. Loss of lives and damage to property and infrastructural assets as a result of natural disasters are a regular phenomenon in the Nepalese economic and social landscape. Nepal's water body consists of more than 6,000 rivers and rivulets with a total length of 45,000 km (Tiwari et al., 2018). In June-August 2017, more than half of the 75 districts of Nepal were impacted by floods and landslides triggered by heavy monsoon rains. Over 1.7 million people were affected (with some 160 persons losing their lives), and 43,000 houses were destroyed. On an average yearly, 290 people lost their lives accounting to over $33.8 \%$ of those who died due to different types of disasters 
(DWIDP, 2008). Each year, floods of varying magnitudes occur due to intense, localized storms during the monsoon months (June to September) in Nepal's numerous streams and rivers (Awal, 2007).

In present case of Kathmandu Valley, excessive rainfall at a time is the basic cause of a river flood but there are simultaneously other contributory factors. Temporarily used backwater effects in sewers and local drainage channels and creation of unsanitary conditions may cause flooding. Also, inundations of large areas are due to overflowing river banks resulting in extensive damage to life and properties (GON, 2013). The River which flows through the centre of main city was found silting due to the improper drainage facilities and encroachment by the local peoples who causes flood (Muthusamy et.al, 2017).

\section{B. OBJECTIVE}

Major Objective of the study is to conduct flood modeling assessment. The specific objective of this study includes:

- Preparation of present land use map

- To conduct flood frequency analysis for different return periods

- To prepare flood vulnerability map of study area according to land cover

- To access the results of flood modeling from two different research for same study area

\section{STUDY AREA}

The study area lies in Bishnumati River of Kathmandu District. The Bishnumati River is one of the major tributaries of the Bagmati River in the Kathmandu Basin. It has six feeder tributaries namely, the Shivapuri khola, Shangla khola, Mahadev khola, Samakhusi khola, Bhachakusi khola and Manamati khola, and flows through densely populated core areas of the city. Shangla khola is large tributary of the Bishnumati River originating from hilly area of Shivapuri range and joins with Bishnumati River at Manohar Tirtha Ghat Bishnumati (GON, 2009). It is a perennial stream fed by storm flow and springs. The average annual rainfall is $1900 \mathrm{~mm}$ of which about $80 \%$ occurs only during monsoon (JulySept). The maximum monthly discharge reaches highest $(3.4 \mathrm{~m} 3 / \mathrm{s})$ in August and is least $(0.024 \mathrm{~m} 3 / \mathrm{s})$ in February according to the data of DHM (1998). The total drainage area of the Bishnumati watershed is 102.09 $\mathrm{km}^{2}$ (Tamrakar, 2009). It originates from the Shivapuri hill at above $2,481 \mathrm{~m}$ in the north of Kathmandu valley and merges with the Bagmati River at the Teku confluence travelling over $15.2 \mathrm{~km}$. The study area was chosen in order to analyze the result of previous done by Dangol (2015) and compare with this present study.

\section{MATERIALS AND METHODS}

One dimensional hydrological modeling was adopted for this study. HEC-RAS was used for modeling and HEC-GeoRAS was used for presentation and analysis.

\subsection{Data Collection}

Satellite image of SAS Planet of year 2019 was used for updating land cover data collected from Survey Department. Freely avilable DEM of $12.5 \mathrm{~m}$ generated from ALOS PALSAR was used to create TIN. Cross section of the river at the bridge section was measured at the field. Stream line, centerline and other necessary input data were prepared from the updated land cover maps.

\subsection{Flood Frequency Analysis}

As per the recommendation of the Water and Energy Commission Secretariat/ Department of Hydrology and Meteorology (WECS/ DHM) of Nepal, the flood flow of any river of catchment area $\mathrm{A} \mathrm{km}^{2}$ lying below $3000 \mathrm{~m}$ elevation are given by the equation developed by WECS and DHM (Sharma, et al., 2003) for 2-year and 100-year floods is adopted for the study.

$\mathrm{Q}_{2}=2.29(\mathrm{~A}<3 \mathrm{~K}) 0.86$

$\mathrm{Q}_{100}=20.7(\mathrm{~A}<3 \mathrm{~K}) 0.72$ 
Where Q is the flood discharge in $\mathrm{m}^{3} / \mathrm{sec}$ and A is basin area in $\mathrm{Km}^{2}$. Subscript 2 and 100 indicate 2-year and 100 year flood respectively. Similarly, subscript 3k indicates area below $3000 \mathrm{~m}$ altitude. Further following relationship (WECS and DHM, 1990) was used to estimate floods at other return periods.

$\mathrm{Qf}=\exp (\ln \mathrm{Q} 2+\mathrm{s} 1 \sigma)$

Where $\sigma 1=\operatorname{In}(\mathrm{Q} 100 / \mathrm{Q} 2) / 2.326$ and $\mathrm{s}$ is the standard normal variate whose values are given in Table 1.

Table 1: Value of standard normal variate.

\begin{tabular}{|c|c|c|}
\hline SN & $\begin{array}{c}\text { Return Period } \\
\text { (Year) }\end{array}$ & $\begin{array}{c}\text { Standard Normal } \\
\text { Vairate (s) }\end{array}$ \\
\hline 1 & 2 & 0 \\
\hline 2 & 5 & 0.842 \\
\hline 3 & 10 & 1.282 \\
\hline 4 & 20 & 1.645 \\
\hline 5 & 50 & 2.054 \\
\hline 6 & 100 & 2.326 \\
\hline 7 & 200 & 2.576 \\
\hline 8 & 500 & 2.878 \\
\hline
\end{tabular}

Source: WECS/DHM, 1990)

\subsection{Flood Modeling}

RAS Geometry in HEC-GeoRAS is used for creating required data sets for creating import file to HEC-RAS. Stream centerline, main channel banks (left and right), flow paths, and cross sections are created with simultaneous referral to Satellite images for verification. The Manning's ' $n$ ' value is highly variable and depends on a number of factors including surface roughness, vegetation, channel irregularities, channel alignment, scour and deposition, obstructions, size and shape of the channel, stage and discharge, seasonal changes, suspended material and bed-load.

Land cover map is used to extract the Manning's $\mathrm{n}$ value based on Manning's Roughness coefficient as shown in table 2 below. These values are extracted for each cross section depending on the intersection of cross-sections with land cover. Finally, after setting up the layer, the file is exported for further processing.
Table 2: Manning's roughness coefficient for different land cover.

\begin{tabular}{|c|l|c|}
\hline S.N & \multicolumn{1}{|c|}{ Land Use code } & $\begin{array}{c}\text { Manning's } \\
\text { value }\end{array}$ \\
\hline 1. & Forest & 0.055 \\
\hline 2. & Cultivation & 0.06 \\
\hline 3. & Sand Area & 0.035 \\
\hline 4. & Bareen Land & 0.04 \\
\hline 5. & Bursh, Grass & 0.055 \\
\hline 6. & Pond & 0.035 \\
\hline 7. & Bulitup Area & 0.08 \\
\hline \multicolumn{2}{|c|}{ Source: Chow, 1990) } \\
\hline
\end{tabular}

In the HEC-RAS, after importing the geometric data extracted from GIS, hydraulic data were entered. The import file created by HEC-geoRAS is imported in Geometric Data Editor interface within HEC-RAS. The flood discharge for different return periods were entered in steady flow data. Reach boundary conditions were also entered in this window. Then, water surface profiles were calculated in steady flow analysis.

After simulation, RAS GIS export file was created and water surface profiles were computed. The flow data were entered in the steady flow data editor for four return periods as 10-year, 20 years, 50-year and 100-year. Boundary condition was defined as critical depth for both upstream and downstream. Sub-critical analysis was done in steady flow analysis. Once the water surface profiles were calculated, the results were exported to GIS format. HEC-RAS model simulation results were exported to HEC-GeoRAS for further processing and visualization of flood extents.

\section{DATA PROCESSING}

All the data processing and modeling were done in HEC-RAS and HEC-GeoRAS platform.

\subsection{RAS Mapping}

In the last step, HEC-RAS results were imported into the GIS system and a floodplain map for each profile is developed. Flood inundation definition was performed that involves the use of HEC-RAS export for 
defining the flood inundation extent followed by water surface generation. Though the cross section data were collected in the bridge section, only the cross section data was used but processing on the basis of bridge and levee position was not conducted in this research. Finally, flood plain was delineated to generate flood inundation and flood depth maps for various return periods.

\subsection{Flood Vulnerability Analysis}

Flood with the same exceed probability will have different levels of vulnerability according to the land cover characteristics and potential for damage. The vulnerability analysis, therefore, consists of identifying the land cover under the potential influence of a flood of particular return period. For this, vulnerability maps were prepared by clipping the land use themes of the floodplains with the flood area polygons for each of the flood events being modeled. The land cover areas under the influence of each of flooding events are reclassified for the calculation of the total vulnerable areas. In this study, land cover vulnerability was analyzed and no other criteria like social, physical, economic, environmental indicators are not included since one of the objective is to analyze with the previous study of this same region and only land cover could be compared between the two research.

\section{RESULT AND DISCUSSION}

This study presented a systematic approach for the preparation of flood vulnerability map with the application of hydraulic model and GIS. The key findings are as follows.

\subsection{Flood Frequency Analysis}

The total catchment area of Bishnumati River was found to be $102.09 \mathrm{~km}^{2}$ for this study. The flow data were entered in the steady flow data editor for four return periods as 10 -year, 20-year, 50-year and 100-year. The discharge for various return periods was calculated by WECS/ DHM method for this study. According to the formulation of WECS the discharge for 10-year is $445 \mathrm{~m}^{3} / \mathrm{sec}, 20$-year is $541 \mathrm{~m}^{3} / \mathrm{sec}, 50$-year is $648 \mathrm{~m}^{3} / \mathrm{sec}$ and 100 year is $725 \mathrm{~m}^{3} / \mathrm{sec}$. The table 3 result shows that the increment of the return period also increases the discharge value of river.

Table 3: Peak discharge for various return period by WECS/DHM method.

\begin{tabular}{|c|c|c|}
\hline S.N. & Return Period & Discharge $\left(\mathrm{m}^{3} / \mathrm{sec}\right)$ \\
\hline 1 & 10 & 445 \\
\hline 2 & 20 & 541 \\
\hline 3 & 50 & 648 \\
\hline 4 & 100 & 725 \\
\hline
\end{tabular}

Form the study it shows the discharge rate increases in 100 years to $725 \mathrm{~m}^{3} / \mathrm{sec}$ comparing to other calculated years. From the obtained results as well, as the return period increases the discharge become maximum. The discharge increases as more water is added through rainfall, tributary streams, or from the groundwater sweeping into the stream resulting in floods due to increase of width, depth and velocity of streams (Shravanya, 2016).

\subsection{Land Cover of the Study Area}

The land cover near Bishnumati River contains cultivation that occupies 66.14 percent of the total land area. The forested area in the surrounding hills covers about 16.78 percent, dry soil and land occupies 3.49 percent and barren land covers about 0.19 percent of total land, whereas the built-up area only covers 13.39 percent of the total land area in which flooded area was digitized to get the results in quick. Table 4 result shows that study area is densely covered by cultivated land, forest area, built-up area whereas dry soil and sand and then barren land are seem to be less covered in compare to other land cover class. Land cover classes such as cultivation land, forest, built up area; barren land lying near the river area has higher probability of flood destruction.

Table 4: Land cover at the study area.

\begin{tabular}{|c|l|c|c|}
\hline S.N. & Land Use class & Area (ha) & $\%$ \\
\hline 1 & Cultivated & 7486.39 & 66.14 \\
\hline 2 & Dry soil and sand & 395.92 & 3.49 \\
\hline 3 & Forest & 1899.75 & 16.78 \\
\hline 4 & Built-up Areas & 1515.76 & 13.39 \\
\hline 5 & Barren land & 22.25 & 0.20 \\
\hline \multicolumn{2}{|c|}{ Total } & 11320.07 & 100 \\
\hline
\end{tabular}




\subsection{Flood Vulnerability Analysis}

The table 5 show that 124 ha, 35 ha, 12 ha and 10 ha of built-up, sand/ barren area, cultivation land and grassland are respectively inundated by 10 - years flood. Similarly, 195, 48, 20, 18,1 ha of built-up area, sand/ barren land, cultivation land, grassland and forest area are respectively inundated by 100 -year flood, which showed flooded area increased with increase in flooding intensity. Mostly, built-up area was inundated by different year floods, which was followed by sand/barren land, cultivation land, grassland land and forest. As form the field evidence, data analysis maps illustrate that flooding of the river is also inundating considerable distance from the river course because of narrow passage of river channel, slum encroachment, and narrowed river width.

Table 5: Land cover vulnerability.

\begin{tabular}{|l|l|c|c|c|c|}
\hline \multirow{2}{*}{ SN } & \multirow{2}{*}{$\begin{array}{c}\text { Land } \\
\text { Cover }\end{array}$} & \multicolumn{4}{|c|}{$\begin{array}{c}\text { Total vulnerable area (Ha) in } \\
\text { different return period }\end{array}$} \\
\cline { 3 - 6 } & & 10 & 20 & 50 & 100 \\
\hline 1 & Cultivation & 11.49 & 13.21 & 14.52 & 19.95 \\
\hline 2 & Sand/Barren & 34.3 & 39.34 & 41.66 & 47.15 \\
\hline 3 & Forest & 0.02 & 0.06 & 0.61 & 0.67 \\
\hline 4 & Grassland & 9.32 & 11.8 & 13.35 & 17.77 \\
\hline 5 & Built-up & 123.93 & 148.11 & 163.69 & 194.63 \\
\hline & Total & 179.06 & 212.53 & 233.83 & 280.17 \\
\hline
\end{tabular}

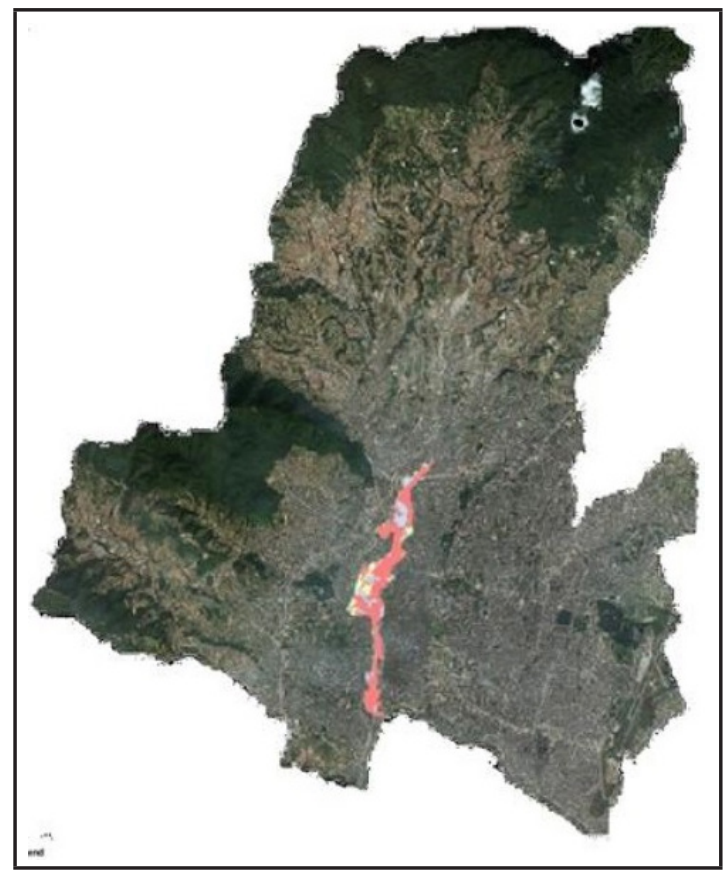

Figure 1: Flood vulnerability map of 10 year return period.

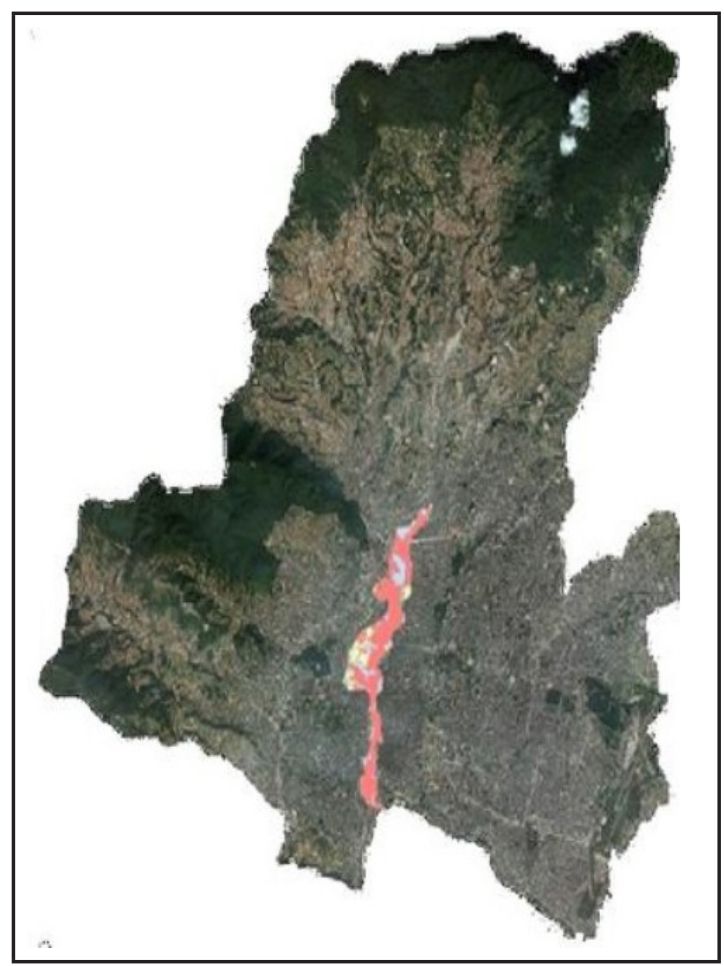

Figure 2: Flood vulnerability map of 20 year return period.

\subsection{Flood Modeling Assessment}

The flood vulnerability modeling result of Dangol (2015), the research which was done in 2009 was taken as the base result for the comparison between the two researches at same study area in different time period. Vulnerability analysis of Bishnumati catchment was done for the return period of 10, 20, 50 and 100 years (Dangol, 2015). Table shows the comparative analysis of flood vulnerability analysis. Since the study done by Dangol (2015) was in 2009, the 20 year return period will be 2029. And for this present research, 10 year return period will be 2029 . Hence, two research done at same area for same period was analyzed.

The past study done by Dangol (2015) show that the total land cover area is mostly covered by built up area with $65.28 \%$ coverage and similarly $48.6 \%$ by sand/barren land, 23.8 by cultivated land, $14 \%$ by grassland and 0.4 $\%$ by forest area whereas also in this study it shows the $69.21 \%$ is densely covered built up area, $19.16 \%$ is sand/barren land, $6.42 \%$ is 
cultivation area, $5.20 \%$ is grassland and 0.01 percent is forest area. The total area inundated in previous study is 250.7 ha and that for this research is 179.06 ha. Though total inundated area is small than the previous study, increase in inundation of the built up area for the same time period clearly showed that there is increase in built up area.

\begin{tabular}{|c|l|c|c|c|c|}
\hline \multirow{2}{*}{ SN } & \multirow{2}{*}{ Land Cover } & \multicolumn{3}{|c|}{ Total vulnerable area (Ha) } \\
\cline { 3 - 6 } & $\begin{array}{c}\text { 20 years of } \\
\text { Dangol study } ~ \\
2029\end{array}$ & $\begin{array}{c}10 \text { year of this } \\
\text { study } ~ \\
2029\end{array}$ \\
\hline 1 & Cultivation & 23.8 & 9.52 & 11.49 & 6.42 \\
\hline 2 & Sand/Barren & 48.6 & 19.44 & 34.3 & 19.16 \\
\hline 3 & Forest & 0.4 & 0.16 & 0.02 & 0.01 \\
\hline 4 & Grassland & 14 & 5.60 & 9.32 & 5.20 \\
\hline 5 & Builtup & 163.2 & 65.28 & 123.93 & 69.21 \\
\hline & Total & 250.7 & 100 & 179.06 & 100 \\
\hline
\end{tabular}

\section{CONCLUSION}

The flood vulnerability analysis has been done with the use of software like HEC-RAS and GIS have wide applications but, in context of Nepal where the availability of river geometric, topographic and hydrological data is limited, the application of mapping is inadequate. The river flooding is highly dependent on the maximum instantaneous flow, river morphology and human interferences. With the use of WECS/DHM method discharge data for 10, 2050 and 100 years return periods was calculated in which the flood intensity was observed as $445 \mathrm{~m}^{3} / \mathrm{sec}, 541 \mathrm{~m}^{3} / \mathrm{sec}, 648^{3} \mathrm{~m} /$ sec, $725 \mathrm{~m}^{3} / \mathrm{sec}$.

It can be concluded that high vulnerability grade is particularly in Baniyatar, Khusibu and Gongabu whereas most of the places like Balaju, Dhalko and Teku are moderate to high vulnerable to flood. The vulnerability assessment of Bishnumati River flooding was performed with the GIS based approach. HEC-geoRAS extension was used to provide interface been the HEC-RAS and ArcGIS platforms.

\section{REFERENCES}

Awal, R. (2007). Floodplain Analysis and Risk Assessment of Lakhandei River. Applied Research Grants Program for Disaster Risk Reduction, Rounds I and II (2003-2006)

Brunner,G. (2016). HEC-RAS River Analysis System: Hydraulic ReferenceManual,Version5.0, USArmy Corps of Engineers-Hydrologic Engineering Center.

Dangol, S. \& Bormudoi, A. (2015). Flood Hazard Mapping and Vulnerability Analysis of Bishnumati River, Nepal. Nepalese Journal on Geoinformatics, Vol 14. Survey Department, Government of Nepal.

Government of Nepal.(2009). Ministry of Water Resources Department of Water Induced Disaster Prevention. The Preparation of Flood Risk and Vulnerability Map of the Kathmandu Valley. Final Annual report.

GoN. (2013). Nepal Hazard Risk Assessment.

Horritta,M.S \& Bates,P.D (2002). Evaluation of 1D and 2D Numerical Models for Predicting River Flood Inundation. Journal of Hydrology 268 (2002) 87-99.

ICIMOD. (2007). Hazard-Specific Flash

Flood Management Measures. Resource Manual on Flash Flood Risk Management-Module 2.

Kumar,P. \& Vergheese,O. (2017). Flood Modelling of Mangalam River Using GIS AND HEC- RAS. International Journal of Advance Research in Science and Engineering, Vol.No .6, Issue No. 06.

Maharjan, L. \& Shakya, N. M. (2016). Comparative Study of One Dimensional and Two Dimensional Steady Surface Flow Analysis. Journal of Advanced College of Engineering and Management, Vol. 2, 2016. 
MoHA. (2009). Nepal Disaster Report 2009. Government of Nepal 2009 2018-10-06 06-29-11.

Muthusamy, S., Muthusamy, N., Ramasamy, T. \& Murugesan, B.(2017). Study and Analysis of Chennai Flood 2015 Using GIS and Multicriteria Technique. Journal of Geographic Information System, 09(02), 126-140. doi: 10.4236/jgis.2017.92009

Rees, G. \& Gustard, L. (2004). Development and Testing of a Flow Estimation Model for Nepal. Centre for Ecology and Hydrology Wallingford, Oxfordshire, OX108BB,U.K., Department of Hydrology and Metereology, Nepal.

Shravanya,S. (2016). Hydrological Study and Estimating Flow Rate of Sungai Lebir, Kuala Krai, Kelantan. Thesis submitted for Bachelor of Civil Engineering to Faculty of Civil Engineering and Earth Resources, Universiti Malaysia Pahang.
Sahid, Nurrohman, \& Hadi. (2018). An investigation of Digital Elevation Model (DEM) structure influence on flood modelling. IOP Conference Series: Earth and Environmental Science, 148, 012001. doi: 10.1088/1755$1315 / 148 / 1 / 012001$

Tamrakar, N. K. (2009). Riverbed-Material Texture and Composition of Bishnumati River, Kathmandu, Nepal; Implications in Provenance Analysis. Bulletin of the Department of Geology, Tribhuvan University, Kathmandu, Nepal, Vol. 12, 2009, pp. 55-62.

Teng, A., Jakeman, A.J, \& Croke, B. (2017). Flood Inundation Modelling: A Review of Methods, Recent Advances and Uncertainty Analysis. Environmental Modelling \& Software, 90, 201-216. doi: 10.1016/j.envsoft.2017.01.006.

Tiwari K. R., \& Rayamajhi S. (2018): Devastating Monsoon: Water Induced Disaster Management Practices in Nepal. Forestry: Journal of Institute of Forestry, Nepal. No. 15: page 57 to 76.

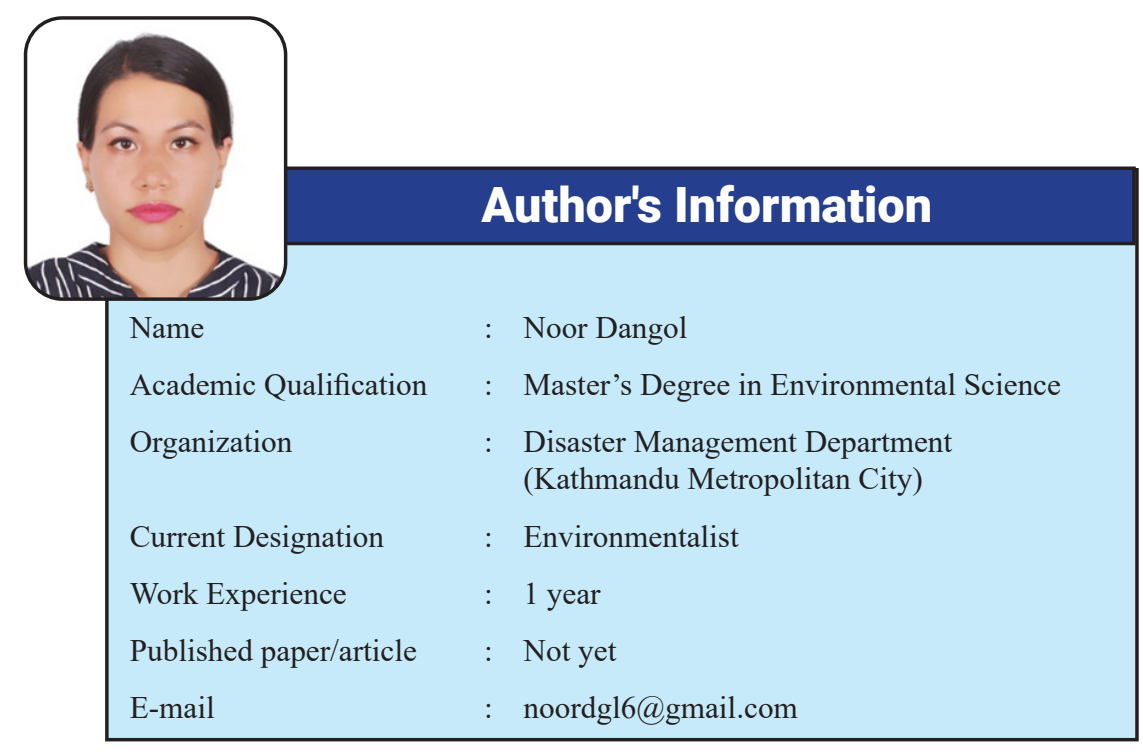

